\title{
THE USE OF FAIES (FIRST AID IN ENGLISH SYSTEM) METHOD TO DEVELOP THE STUDENTS' WRITING ABILITY
}

\author{
Abd. Rajab, Rahmiani \\ English Education Department, Faculty of Teacher Training and Education \\ Muhammadiyah University of Makassar \\ rajabchoro@gmail.com
}

\begin{abstract}
This research aimed to find out the improvement of the students' writing ability in term of grammar covering simple past tense and past continuous tense and vocabulary covering verb and noun especially in recount text at the eighth grade students of SMP Unismuh Makassar. The researcher used a classroom action research (CAR) which was conducted in two cycles where each cycle consisted of four meetings and the application consisted of four steps namely planning, action, observation and reflection. The technique of collecting data is writing test and observation and technique of data analysis is quantitative. The number of the research subject was 26 students in class $V I I I_{B}$ and all the students were male. The research findings indicated that using FAIES method could improve the students writing ability in terms of grammar and vocabulary. It was proved by the students' mean score in the test of cycle II, the result was (75.25) which increased $15.15 \%$ from the cycle I mean score (60.1). It was highly increased from diagnostic test (D-test) mean score (48.2). The students' achievement in cycle II indicated that it had met the researcher score target (75) where the classification of students' score were 4 students got excellent score where the percentage was 15.4\%, 11 students got good score where the percentage was 42.3\%, 10 students got fair score where the percentage was $38.5 \%$ and 1 student got poor score where the percentage was 3.8\%. Based on the findings of the research above, the researcher concluded that FAIES method were successful in improving the students' writing ability covering grammar and vocabulary for recount text at the eighth grade students of SMP Unismuh Makassar class VIIIB .
\end{abstract}

Keyword: FAIES, develop, writing, ability

Writing is one of the language skills that play important roles in human communication because it is a necessary and important area of literacy that supports comprehension, critical and creative thinking across areas. It is a form communication where people can express their idea, feeling, and knowledge. It is the skill that processed by human being to produce his or her ideas and thought into written-forms (paper), although the ideas or thought can also produce through spoken-forms. Sometimes people cannot express their opinion or their ideas orally but they can express them through writing in order they can transmit their idea. Therefore, it cannot be denied that writing skill is very important to master because, writing can make us communicate with the other in the world without talking or meet each other; it is something, which we always do now in global era. Another effectiveness of writing especially in academic is when we write on a 
subject, it will make us be active learners rather than passive receiver of information like I write then I remember. It also helps us absorb and process information from a topic that we are going to write and we will be deeply involved to the subject in order to get good sense.

Another beneficial of writing is it is important for many aspects of social, practitioners, and professional of communication. Those who have difficulties in expressing themselves in writing are handicapped in society. Schwegler in Sudarman (2011) also explained that writing is one of the hardest things that people do because it requires thinking. He also said that, there are several components in writing that should be mastered in writing such as grammatical structure, vocabulary, coherence, organization, and content. Those components are related to one another in order to produce a good writing. The absence of one of those components will produce poor result of writing.

As we know, one of the most difficult of language skills is writing. The ability to write strongly dealt with the use of punctuation, structure, vocabulary, and organization of paragraph. On the other hand, writing is one way to develop our opinion, ideas, or our thought for formal or informal sentences. And also there are many aspects that make students cannot write well, such as; they do not have enough ideas to write, they cannot generate a good writing, the class climate does not support or probably they do not understand what they must do. But more than all, there are two classic problems that to be some causes why the students cannot write in English language because they are less the vocabulary and cannot use grammar in their writing. It makes the students lazy to write by using English language. In this case, the researcher has found similar case among the student of SMP Unismuh Makassar especially at class VIII $\mathrm{B}$. According to English teacher of SMP Unismuh Makassar, the biggest problem of the students to write in English language, because they are lack vocabulary and they cannot write a paragraph and even a sentence with correct grammar. Furthermore, even they have an idea on their head they cannot write it down.

Based on the result of diagnostic test at $\mathrm{VIII}_{\mathrm{B}}$ class of SMP Unismuh Makassar, the mean score of the students' achievement in writing English was very low. It was about 48.2 mean score but the standard of curriculum (KKM) 
was 70 and the target score is 75. To make them easy in writing an English sentence, teachers have to find a good teaching method to solve this problem because students need a structured and supportive environment to be able to practice the writing habits and processes of successful writers. One of good teaching method which offers by the writer is First Aid in English System (FAIES). The use of FAIES method will be helpful the student to develop their ability in writing. It is a flexible method which can adapt with each situation and each material so the students never boring to follow the teaching and learning process. Giving the students real object and match the situation with the material facilitates the students to understand the material. Teaching by using target language but apply it in direct action makes the student get any new vocabularies by analyzing, and teaching grammar by giving lots of examples than stress on pattern so the students apply grammar rules as habitual either in speaking and writing.

How does FAIES method improve of the students' vocabulary in writing skill at the eight year students of SMP Unismuh Makassar?

How does FAIES method improve the students' writing skill in terms of grammar at the eight year students of SMP Unismuh Makassar?

The result of this research is expected to be useful contribution for the teacher of English writing to find out and to analyze the students' proficiency in writing, to give useful information for teaching and learning process in developing the students' ability in writing. The scope of this research limited to the application of FAIES to develop the students' ability in writing for recount text at the VIII $_{\mathrm{B}}$ grade students of SMP Unismuh Makassar. The writing assessment focused on vocabulary, which consist of verb and noun and grammar, which consist of simple past tense and past continuous tense.

\section{FAIES (First Aid in English System)}

FAIES is the best and unique method in teaching because it is a flexible method which can adapt with any situation in the classroom and use many ways in teaching which makes the students fell easy to understand the lesson especially in English writing through enjoyable way. According to Freud in Wollheim (1981), 
FAIES (First Aid in English system) is the teaching method to emphasize or stress on communication which consist of directional approach, functional approach, situational approach, and drilling technique. It is actually merging from those 3 approaches and 1 technique. This is the best method for the teacher because this method is flexible. When the situation in the class is change this method can follow the situation by situational approach. So the students never fell boring to follow teaching and learning process. Based on the subject of this research is junior high school this method is suitable for young students which do not have basic in English language.

Freud in Wollheim (1981) implies that this method merging from three approaches and one technique and it has characteristic based on the approach and technique which is underlying this method. The characteristics as follow:

\section{Directional Approach}

Directional approach sometimes also called direct method or natural approach. It is a method for teaching foreign languages that refrains from using the students' native language and just uses the target language. It was established in Germany and France around 1900.This approach was developed initially as a reaction to the grammar-translation approach in an attempt to integrate more use of the target language in instruction. Furthermore, it is a teaching approach for teachers to use the target language by giving a real object or sample such as pictures or video that related to the teaching material, a good model of pronunciation, demonstration and action in explaining the new things or lessons.

The advantages of directional approach are:

1. It makes the learning of English interesting and lively by establishing direct bond between a word and its meaning.

2. It is an activity method facilitating alertness and participation of the pupils.

3. It is the quickest way of getting started. In a few months over 500 of the commonest English words can be learnt and use in a sentences. This serve as a strong foundation of further learning. 
4. Due to application of this approach, students are able to understand what they learn, think about it and then express their own ideas in correct English about what they have read and learnt.

5. In psychological side, it is a sound method or approach as it proceeds from the concert to the abstract.

6. This approach can be usefully from the lowest to the highest class.

7. Through this approach, fluency of speech, good pronunciation and power of expression are properly developed.

8. In addition, through this approach, the students are encouraged to automatically say the English words without feeling shy or afraid of making mistakes.

\section{Functional Approach}

It is a teaching approach for teachers to explain the grammars without using formula, but rather than give many sentences and speaking patterns. The benefit of this approach is the students are strongly asked to use the sentences correctly to communicate with others.

In functional approach, teacher should know the function of the language. In teaching English, teacher must tell students what is the function of every tenses, or grammar. The function of each grammar and how to make a correct sentence that is using grammar. Teacher must teach students clearly in the function of grammar. Functional approach is similar with grammar translation method.

\section{Situational Approach}

This approach developed by British applied linguists in the 1930s, and it has survived, so far, by completing later approaches and methodologies such as Audio-Lingual Method, Communicative Language Teaching, Total Physical Response, The Silent Way, Community Language Learning, the Natural Approach, Suggestopedia, etc.

The view of this approach is to insure that the language that is being taught is realistic, all the words and sentences must grow out of some real situation or imagined real situation. Thus, the meanings of words are tied up with the situations in which they are used. The students know the meaning of the word "blackboard", not because they have looked it up in a dictionary, but because they 
have learned the word in situations; by hearing commands such as: "Look at the blackboard!"; “Clean the blackboard!”, "Write on the blackboard!" This example stresses the association between the word "blackboard" and the action of "looking at it", "cleaning it", or "writing on it. Even if the classroom environment is limited, the teacher's inventiveness should be put into practice in the pretence of a situation picked up from outside the classroom. That is why, this approach stress the teachers to create or develop teaching situations based on the lesson that is explained and give practice which mostly be done in airs, role plays, drama or simulations. The situational environment should be presented in such a way that even the slowest students gets involved in what the teacher or the other students do and say in the classroom. The idea of making the students cooperate with one another underlines the social touch of this approach. Students are always eager to take part in make-believe situations, especially when they assume roles and enact a situation before the rest of the class.

The theory backing up the Situational Approach includes the following principles:

1.) Language learning is habit-formation

2.) Mistakes are bad and should be avoided, as they make bad habits.

3.) Language skills are learned more effectively if they are presented orally first, then in written form.

4.) Analogy is a better foundation for language learning than analysis.

5.) The meanings of words can be learned only in a linguistic and cultural context.

Since it is an approach, the tenets of Situational Language Teaching can be carried out by several methods: i.e. the Audio-lingual Method, the Direct Method, Community Language Learning, etc.

\section{Drilling Technique}

Drilling is a technique that has been used in foreign language classrooms for many years. It was a key feature of audio-lingual method approaches to language teaching, which placed emphasis on repeating structural patterns through oral practice.

It is a teaching technique for teachers to drill the students by asking them to repeat after teachers to make them remember about the lesson, even after they 
have already arrived home and have done other activities. Drilling means listening to a model, provided by the teacher, or a tape or another student and repeating what is heard. Drilling is a technique that is still used by many teachers when introducing new language items to their students. Harmer (1991), states that drilling is mechanical ways if getting students to demonstrate and practice their ability to use specific language items in a controlled manner.

From those theories above, it can be concluded that drilling is a technique that has been used in foreign language classrooms which emphasis on repeating structural pattern through oral practice to demonstrate students' ability in using specific language items in a controlled manner. The purposes of drilling for the teacher and student are:

\section{Students:}

1. Provide for a focus on accuracy. Increased accuracy is one of the ways in which a learner's language improves so there is a need to focus on accuracy at certain stages of the lesson or during certain task types.

2. Provide learners with intensive practice in hearing and saying particular word or phrases. They can help learners get their tongues around difficult sounds or help them imitate intonation that may be rather different from that of their first language.

3. Provide a safe environment for learners to experiment with producing the language. This may help build confidence particularly among learners who are not risk takers.

4. Help students notice the correct form or pronunciation of a word phrase. Noticing or consciousness rising of language is an important stage in developing language competence.

5. Provide an opportunity for learners to get immediate feedback on their accuracy in terms of teacher or correction. Many learners want to be corrected.

6. Help memorization and atomization of common language patterns and language chunks. This may be particularly true for aural learners.

7. Meet students expectation, i.e. they may think drilling is an essential feature of language classrooms. 


\section{Teacher:}

1.) Help in term of classroom management, enabling us to vary the pace of the lesson or to get all learners involved.

2.) Help the teacher recognize if new language is causing problems in terms of form or pronunciation.

\section{CONCEPT OF WRITING}

According to Byrne (1990), writing can be said to be the act of forming these symbols: making marks on a flat surface of some kind. But writing is clearly more than the production of graphic symbols, just as speech more than the production of sounds. In Cambridge Advance Learner's Dictionary at the third edition that writing is the activity of creating pieces of written work, such as stories, poems or articles.

The process of the written is how to create the creative idea and write down into essay from Gebhard in Rini (2011). According to Cox in Sulmiati (2007), writing is a way of knowing of discovery what we want to know as we put it down not only in the form of words and phrases but also scribble and drawing ideas and image, and all the other wonderful stuff in our mind that may only become clear as we engage the process of writing down. In other word, we do not know what we are going to write about until we write it.

From all of the statements above, the writer concludes that writing is a tool of communication which used to express the idea in our mind and send the messages from the writer to the reader in written materials.

\section{The Importance of Writing}

There are many reasons why writing is important, are:

a. Writing is the primary basis upon which your work, your learning, and your intellect will be judged in college, in the workplace, and in the community.

b. Writing expresses who you are as a person.

c. Writing is portable and permanent. It makes your thinking visible.. 
d. Writing helps you move easily among facts, inferences, and opinions without getting confused and without confusing your reader.

e. Writing promotes your ability to pose worthwhile questions.

f. Writing fosters your ability to explain a complex position to readers, and to yourself.

g. Writing helps others give you feedback.

h. Writing helps you refine your ideas when you give others feedback.

i. Writing requires that you anticipate your readers' needs. Your ability to do so demonstrates your intellectual flexibility and maturity.

j. Writing ideas down preserves them so that you can reflect upon them later.

k. Writing out your ideas permits you to evaluate the adequacy of your argument.

1. Writing stimulates you to extend a line of thought beyond your first impressions or gut responses.

m. Writing helps you understand how truth is established in a given discipline.

n. Writing equips you with the communication and thinking skills that you need to participate effectively in democracy.

o. Writing is an essential job skill.

Raimes in Rini (2011) also states that some reasons about the importance of writing. According to him, writing is helpful the students, the reasons for that are:

a. Writing reinforces the grammatical structures, idiom, and vocabulary that have been taught to the students.

b. When the students write, they also have chance to be adventurous with the language, to go beyond what they have learned to say, to take risk.

c. What the students write, they necessarily become very involved with the new language; the effort to express ideas or thinking on paper.

\section{Characteristics of Good Writing}

What are the criteria of good writing? To defining good writing is almost difficult. Some readers cannot be defined it but they know that a piece of 
writing good or not when they have read it. So, good writing is "community standards" differ from community to community and from discipline to discipline, even to the point of flat contradiction between various disciplines consider good or merely competent writing. But generally speaking, we can agree on the following:

a. Clarity and focus

In good writing, everything makes sense and readers do not get lost or have to reread passages to figure out what is going on. Focused writing sticks with the plot or core idea without running off too many tangents.

\section{b. Organization}

A well-organized piece of writing is not only clear, it is presented in way that is logical and aesthetically pleasing. We can tell non-linear stories or place your thesis at the end of an essay and get away with it as long as your scenes or ideas are well ordered.

\section{c. Ideas and themes}

It is the topic of the paper relevant? Does the story come complete with themes? Can the reader visualize the poem or the other product of writing? For a piece of writing to be considered well crafted, it has to contain clearly identifiable ideas and themes.

\section{d. Voice}

This is what sets you apart from all other writers. It is our unique way of stringing words together, formulating ideas, and relating scenes or images to the reader.

\section{e. Language (word choice)}

We writers can never underestimate of fail to appreciate our most valuable tools - words. Good writing includes smart word choice and well-crafted sentences.

\section{f. Grammar and style}

Many writers would wish this one away, but for a piece of writing to be considered good (let alone great), it has to follow the rules of grammar (and break those rules only when there is a good reason). Style is also important 
in ensuring that a piece of writing is clear and consistent. Make sure that we keep a grammar book and style guide handy.

\section{g. Credibility or believability}

Nothing says bad writing like getting the facts wrong or misrepresenting oneself. In fiction, the story must be believable (even it is impossible) and in nonfiction, accurate research can make or break a writer.

h. Thought - provoking or emotionally inspiring

Perhaps the most important quality of good writing is how the reader responds to it. Does she or he come away with a fresh perspective and new ideas? Does he close the cover with tears in his eyes or sense of victory? How readers react to your work will fully determine your success as a writer.

\section{CONCEPT OF RECOUNT TEXT}

There are some types of text taught in junior high school: descriptive text, procedural text, recount text, and narrative text. Recount text is taught to eighth grade students in Junior High School based on Standard Competencies and Basic Competencies. Hornby (1985) states that a recount is to tell somebody about something, especially something that someone has experienced. A recount text is a text that tells about something that happened to retells past events or activities and has a purpose to give detailed information about what and when of that events.

A recount text usually uses the past tense covering the simple past tense, the past continuous tense, or the past perfect tense. There are a number of reasons on why people may write about the past. This refers to some three types of recount text, among other are:

1) A Personal recount is retelling of an activity that the writer or speaker has been personally involved (e.g. oral anecdote, diary entry)

2) A factual recount is recording the particulars of an incident (e.g. report of science experiment, police report, news report, historical account)

3) An imaginative recount tells about an imaginary story and gives a detail of events (e.g. a day in the life of a roman slave) 
There are three generic structures of recount texts, namely, orientation, series of events, and reorientation. First, orientation is an introduction of events or experiences. It provides basic information about the story such as who was involved, what happened, where this event took place and when it happened so readers or audiences understand the text easily. In addition, setting and characters are introduced. Second, series of events are called as body of text. The series of events are usually written in chronological order or sequence. This stage includes how problems deal with, how characters within the text feel about the events, and how the event told in detail.

Third, reorientation is stating a personal comment of the writer to the story or concluding the text. In this stage, the writer summarizes the events is ended and any issue or problems are completely resolved by characters.

\section{A. Conceptual Framework}

Learning process is the main activity in this research. There is interaction between teacher and the students and valuable educative. Teaching and learning process is done and guided to reach the maximal result. To reach the maximal result, the teacher must be able to design the learning model based on the material subject and to practice the students' writing. The teacher designs and plans teaching activity based on the teaching program. The teacher should master the teaching method in order the students can understand the subject easily. The role of teachers as educator is very complex not just limited when the learning and teaching process running out, but the teachers also as administer, evaluator, counselor and so on, based on their capability. In teaching and learning activity, many factors to develop the students' writing ability, one of them is applying FAIES method in teaching.

In improving the Students writing ability focus on vocabulary and grammar, teacher use CAR (Classroom action research) to apply FAIES method which consists of planning, action, observation and reflection in each cycle. Referring to the previous explanation about FAIES method in order to have a good command, for more understanding about the applying of FAIES method in writing, the conceptual framework underlying this research is presented in the following diagram: 


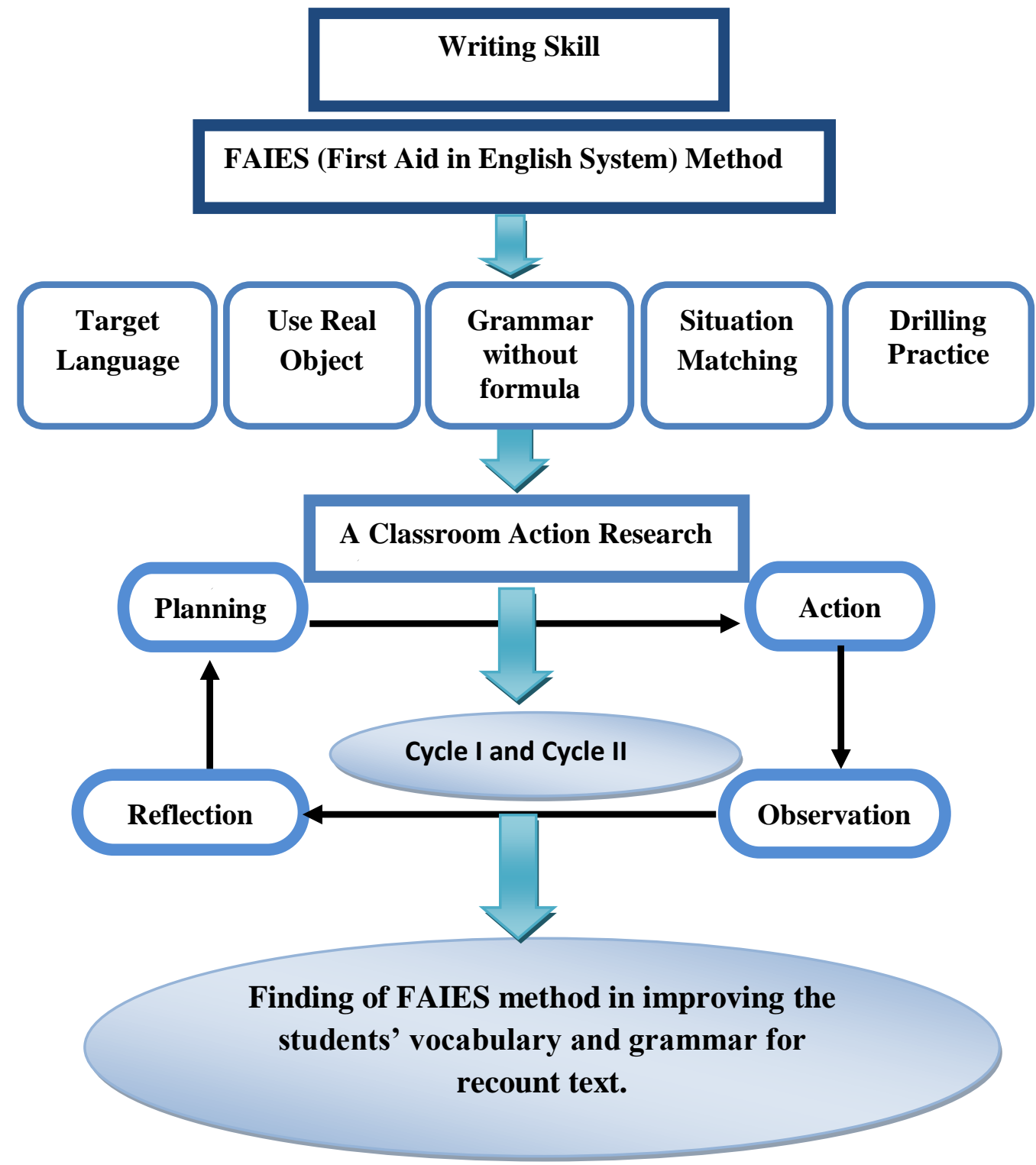

RESEARCH METHOD

In this research, the teacher used CAR (Classroom Action Research) principle to collect the data. It was conduct through two cycles, where each cycle consisted of four phases. They were planning, action, observation and reflection.

\section{Cycle I}

The first cycle consisted of planning, action, observation and reflection as follows:

\section{Planning}

Before started to teach the teacher prepared the materials for teaching the students. So that, the teacher did not confuse what he or she should teach to his or her students when stayed in front of the students. The plan as follows:

a. The teacher made lesson plan after getting the problems. 
b. The teacher made an instrument evaluation that would use in classroom action research cycle.

c. The teacher made format of an observation sheet to see the condition of students in the teaching process

\section{Action}

The action was the process of teaching and learning and this process had been suited by applying FAIES method as follow:

a. The teacher gave motivation to the students to elicit curiously about what the teacher was going to explain by opening up their mind by motivation session.

b. Teacher divided the students in pair then asked them to sit together their partner.

c. Teacher divided each duo students the picture or other real object which related to the material, then asked them to analyze it.

d. Teacher asked the students about information that they had got from the pictures and gave explanation about the picture.

e. Teacher used target laguage when teaching which was sometimes followed by the native language. Then explained the grammatical side without using formula, but rather than gave many examples of sentences and pattern in spoken way.

f. The teacher gave the students good model of pronunciation if there was unfamiliar word for them then asked them to repeat it.

g. Teacher asked each duo to write the recount text based on the pictures and apply the grammar pattern when they write.

h. Teacher reminded about the last session's subject in order the students could understand about the materials as a whole.

\section{Observation}

In the observation, phase the researcher observed by using observation sheet. This observation as follow:

a. Situation of teaching and learning activity

b. The students' present

c. The students' respond of the material 
d. The students' achievement

4. Reflection

After collecting data, the researcher evaluated the teaching learning process. Then, the researcher reflected herself by seeing the finding of the observation, whether the teaching learning process of writing by using FAIES was good to employ in teaching and learning process. After reflecting the researcher found that the students could create a piece of recount text if they worked in pair but when they did it individually they found some difficulties. Considering this problem the researcher decided to conduct the next cycle.

\section{Cycle II}

After cycle I had finished, the result of the teaching and learning process by using FAIES method found that there was improvement of students' writing ability but it was not significant with target that was expected by the researcher. So, cycle II was taken to improve the cycle achievement. Basically, the planning at the first cycle and the second cycle had the same steps. In this cycle, the researcher tried to improve some deficits on the first cycle by changed the situational environment in the class room where in the first cycle the students worked in pair but at the second cycle, the researcher asked the students work individually.

The first cycle consisted of planning, action, observation and reflection as follows:

1. Planning

Before started to teach the teacher must prepared the teaching materials for students. So that, the teacher did not confuse what he or she should teach to his or her students when stayed in front of the students. The plan as follow:

a. The teacher made lesson plan after getting the problems in the previous cycle from the reflection.

b. The teacher made an instrument evaluation that would be used in classroom action research. It was adapted from the result of cycle I.

c. The teacher made format of an observation sheet to see the condition of students in the teaching and learning process. 


\section{Action}

The action at cycle II adapted based on the result of the reflection of previous cycle in teaching materials and the activity which instructed by the teacher in the teaching and learning process.

a. The teacher gave motivation to the students to elicit curiously about what the teacher was going to explain by opening up their mind by motivation session.

b. Teacher used target laguage about $70 \%$ during teaching and learning process that following with the translation in the first language.

c. The teacher gave the story picture as real object to the students and let the students analyzed about that picture.

d. The teacher asked the students about what information that they had got from the picture and asked them to write a piece of recount text about the pictures individually.

e. Teacher controlled the students while they did the assignment then when the teacher got the students error, the teacher directly corrected and gave explanation.

f. The teacher gave the students good model of pronunciation if there was unfamiliar word for them then asked them to repeat it.

g. Teacher reminded about their error in their tasks and gave some explanations which were needed by the students.

\section{Observation}

In the observation phase the researcher did observation by using observation sheet. This observation as follow:

e. Situation of teaching and learning activity

f. The students' present

g. The students' respond to the material

h. The students' achievement

4. Reflection

The data value from evaluation gathered for data analysis, so the researcher could reflect data value of evaluation at the cycle II. 


\section{RESEARCH VARIABLES AND INDICATOR}

1. Variables

The variable was one of very important element of research, this research used two kinds included of variables as follow:

1. Independent variable

Independent variable of the research was the use of FAIES method in teaching writing skill.

2. Dependent variable

Dependent variables consisted of the students' developing in writing focused on vocabulary and grammar.

2. Indicators

The indicators of this research were:

1. The indicators of the students' writing vocabulary were noun and verb.

2. The indicators of the students' writing grammar were simple past tense and Past continuous tense.

\section{RESEARCH SUBJECT \& INSTRUMENT}

The subject of this research conducted at the eight year students of SMP Unismuh Makassar in 2012 academic year in class VIII ${ }_{B}$ that consisted of 26 students at South Sulawesi. In this classroom action research, the research instruments that used were test and observation.

1. The researcher used writing test to asses and examined the students' writing ability. The teacher gave test in last of cycle to find out the improvement of the students' writing ability. The test that had given to the students related with recount text after FAIES method was implemented in teaching and learning process. The Instrument that used was essay test. The researcher gave 1 number essay test; the students asked to make a piece writing in recount text.

2. Observation sheet was used to collect data about the students' participation in teaching and learning process in writing through the implementing FAIES Method. 


\section{THE PROCEDURE OF COLLECTING DATA}

1. The data sources: the data sources in this research were the Eighth Grade Students of SMP Unismuh Makassar. The type of the data which was used consisted of:

a.) The result of the study as quantitative data

b.) The result of the observation as qualitative data

2. The way in taking data

a.) The result of students' data got by giving the test to the students.

b.) The activity of students' data in the class action research got from the process of observation format.

\section{DATA ANALYSIS}

1. Writing test

There were some categories in giving students' writing score achievement.

\section{Scoring rubrics of writing}

a. Rubric Scoring of Simple Past Tense

\begin{tabular}{|c|l|}
\hline Score & \multicolumn{1}{c|}{ Criteria } \\
\hline 4 & $\begin{array}{c}\text { Excellent; There are almost no errors in the use of simple past } \\
\text { tense. }\end{array}$ \\
\hline 3 & Good; There are few errors in the use of simple past tense \\
\hline 2 & Fair; There are many errors in the use.simple past tense. \\
\hline 1 & $\begin{array}{l}\text { Poor: almost all sentences contain errors in the use of simple } \\
\text { past tense. }\end{array}$ \\
\hline 0 & Very poor; Does not use simple past tense correctly. \\
\hline
\end{tabular}

b. Rubric Scoring of Past Continuous Tense

\begin{tabular}{|c|l|}
\hline Score & \multicolumn{1}{|c|}{ Criteria } \\
\hline 4 & $\begin{array}{l}\text { Excellent; There are almost no errors in the use of past } \\
\text { continuous tense. }\end{array}$ \\
\hline 3 & $\begin{array}{l}\text { Good; There are few errors in the use of past continuous } \\
\text { tense. }\end{array}$ \\
\hline 2 & Fair; There are many errors in the use past continuous tense. \\
\hline 1 & $\begin{array}{l}\text { Poor: almost all sentences contain errors in the use of past } \\
\text { continuous tense. }\end{array}$ \\
\hline 0 & Very poor; Does not use past continuous tense correctly. \\
\hline
\end{tabular}

(Marshall, 2012: 45)

c. Rubric Scoring of Verb

\begin{tabular}{|c|l|}
\hline Score & \multicolumn{1}{|c|}{ Criteria } \\
\hline 4 & $\begin{array}{l}\text { Excellent; There are almost no errors in the use of action } \\
\text { verb and sensing verbs. }\end{array}$ \\
\hline
\end{tabular}




\begin{tabular}{|c|l|}
\hline 3 & $\begin{array}{l}\text { Good; There are few errors in the use of action verb and } \\
\text { sensing verbs. }\end{array}$ \\
\hline 2 & $\begin{array}{l}\text { Fair; There are many errors in the use of action verb and } \\
\text { sensing verbs. }\end{array}$ \\
\hline 1 & $\begin{array}{l}\text { Poor: almost all sentences contain errors in the use of } \\
\text { action verb and sensing verbs. }\end{array}$ \\
\hline
\end{tabular}

d. Rubric Scoring of Noun

\begin{tabular}{|c|l|}
\hline Score & \multicolumn{1}{|c|}{ Criteria } \\
\hline 4 & $\begin{array}{l}\text { Excellent; Properly changed all common nouns into } \\
\text { proper nouns, Can identify and spell each noun(s) in all of } \\
\text { the sentences correctly. }\end{array}$ \\
\hline 3 & $\begin{array}{l}\text { Good; There are few errors in changed the common nouns } \\
\text { into proper nouns, identified and spelled each nouns in all } \\
\text { of the sentences. }\end{array}$ \\
\hline 2 & $\begin{array}{l}\text { Fair; There are many errors in changed the common nouns } \\
\text { into proper nouns, identified and spelled each nouns in all } \\
\text { of the sentences. }\end{array}$ \\
\hline 1 & $\begin{array}{l}\text { Poor; almost all sentences contain errors in changed the } \\
\text { common nouns into proper nouns, identified and spelled } \\
\text { each nouns. }\end{array}$ \\
\hline
\end{tabular}

(Arter, 2012:21)

In giving score with the students' ability in writing there were some categories that used by the researcher, as follows:

1. Calculating the score of the students' writing test by using following formula:

Score $=\frac{X}{N} \times 100$

Notation:

$\mathrm{X}=$ Score of the students

$\mathrm{N}=$ Score maximum

$100=$ Standard score

(Heaton, 1988:

146)

2. Calculating the mean score of the students' writing test by using the following fomula:

$$
\bar{X}=\frac{\sum X}{N}
$$

Where: $\bar{X}=$ Mean

$\sum X=$ The sum of all the scores

$\mathrm{N}=$ The total number of the students

(Gay, 1981: 357)

3. To know the development of the students writing between cycle I to cycle II, the researcher used the percentage technique.

$$
\mathrm{P}=\frac{X 2-X 1}{X 1} x 100
$$


Notes: $\mathrm{P} \quad$ : Percentage of the students

$\mathrm{X} 1$ : The mean score of the cycle I

$\mathrm{X} 2$ : The mean score of the cycle II

(Sudjana in Muayada: 2012)

4. Calculating the percentage of the students' activity in learning process by using the following formula:

Where: $\mathrm{P}=$ Percentage

$$
\mathrm{P}=\frac{F}{N} X 100 \%
$$

$\mathrm{F}=$ Frequency

$\mathrm{N}=$ Number of students

(Sudjana in Ediawati 2012)

There were five classifications of students' score as follows:

Table 2. Scoring classification of writing

\begin{tabular}{|c|c|c|}
\hline No. & Classification & Score \\
\hline 1 & Excellent & $86-100$ \\
2 & Good & $70-85$ \\
3 & Fair & $56-69$ \\
4 & Poor & $41-55$ \\
5 & Very poor & $\leq 40$ \\
\hline
\end{tabular}

The researcher converted classification of the students' score, the researcher extends score 85 as maximum or excellent classification. To classify the students' score, there were 3 classifications which were used as follows:

\begin{tabular}{|c|c|}
\hline Score & Classification \\
\hline $75-85$ & Excellent \\
\hline $60-70$ & Very good \\
\hline $40-50$ & Fairly good \\
\hline
\end{tabular}

2. Observation

Analyzing the students' participation in research toward the material and activities in teaching and learning process, it was used observation sheet by checklist. The students' active participation was described as follow:

\begin{tabular}{|c|c|c|l|}
\hline No. & $\begin{array}{c}\text { The students' Active } \\
\text { Participation }\end{array}$ & Score & \multicolumn{1}{|c|}{ Indicator } \\
\hline 1 & Very active & 4 & $\begin{array}{l}\text { Students' respond to the material } \\
\text { very active }\end{array}$ \\
\hline 2 & Active & 3 & $\begin{array}{l}\text { Students' respond to the material } \\
\text { actively }\end{array}$ \\
\hline 3 & Fairly active & 2 & $\begin{array}{l}\text { Students' respond to the material } \\
\text { just once or twice }\end{array}$ \\
\hline 4 & Not active & 1 & $\begin{array}{l}\text { Students just sit down during the } \\
\text { activity without doing something. }\end{array}$ \\
\hline
\end{tabular}

(Hasan in Ediawati, 2011) 
Percentage the students' participation through the following formula: $\mathrm{P}=\frac{F q}{4 \times N} \times 100$

$$
\text { Where: } \quad \begin{array}{ll}
\mathrm{P} & =\text { Percentage } \\
\mathrm{Fq} & =\text { Sum of all the students'score } \\
\mathrm{N} & =\text { Total students }
\end{array}
$$

(Sudjana in Ediawati, 2012)

\section{FINDINGS AND DISCUSSION}

This chapter consists of the findings of the research and discussion that contains of data analysis in detail. The findings of the research cover the result of the data cycle I and cycle II about students' ability in writing and observation result. The findings of classroom action research are deal with the answer of the problem statement which the aim is to improve the students' skill in writing especially recount text. The findings consist of students' skill in writing and observation result. The data of writing skill consists of two items namely: grammar and vocabulary in diagnostic test, cycle I and cycle II.

The researcher observes many aspects to assess the implementation of FAIES method. The students show their progress in every meeting. In attitude the researcher observes about students' participation in learning by using FAIES method, are they active or passive. The next, the researcher observes students' respond during teaching and learning process, are they good or bad. The researcher also observes the students' understanding, do they get the point of subject matter or not. In the first meeting the researcher finds that the students still difficult in writing by using correct grammar and vocabulary in creating a recount text. The students have less motivation, because they feel not confidence with their writing result.

The researcher resolves this problem by using FAIES method. By using this method the researcher tries to solve the students' difficulty in grammar by gives them lots of example. They are stimulated to find the grammar pattern with their own by observing many examples which given. Then the researcher tries to solve the students' poor in vocabulary by using target language more than native language, the purpose is make them accustomed hear the target language which naturally add their vocabulary, if there an unfamiliar word for the students, the 
researcher explains the meaning and demonstrates good model of pronunciation then asks them to repeat it and then the researcher put students in pair. In a pair, they work together to analyze the pictures or other real object which is given by the researcher. Then every group makes a recount text based on the pictures.

The researcher observes students' correspond every meeting. The result of the observation that have been done by researcher concludes that FAIES method improves students' correspond. The students admit that they enjoy this method. They do not feel bored, but more enthusiastic to follow the teaching learning process. The students looked braver and more confident to write and express their ideas regularly in their writing. They also admit that they become active and full of concentration in the classroom.

The use of FAIES method especially always use target language, serves real object from their surrounding and makes the students in pair, group or individually can make the students more active and it causes the improvement of their writing skill. The improvement of students can be seen in the improvement of students' score. The result of test shows the significant improvement. The use of FAIES method in teaching writing can overcome the students' difficulty in expressing their ideas. The students also have a positive response to the implementation of teaching writing by using FAIES method.

The students' writing skill can be improved trough FAIES method, because in this method they can share with their friends in their own pair, which makes easily understand and real object which is given for them make them easily to get the ideas for writing. If they get difficulty in the terms of grammar, FAIES method can reduce this problem by directional approach where teacher directly explain to each students who has problem about it and if they have problem about vocabulary drilling technique as the content of FAIES method can reduce it by telling them the words that they need and gives good model of pronunciation and asks then to repeat so that they remember that words even they have went home.

\section{The Students' Writing Skill in Grammar}

The improvement of the students' writing skill in grammar at the eighth grade students of SMP Unismuh Makassar as result of the students' assessment of cycle I and cycle II is described as follows: 
Table 1: The Students' Improvement in Grammar

\begin{tabular}{|l|c|c|}
\hline \multirow{2}{*}{ Grammar } & \multicolumn{2}{|c|}{ Mean scores (\%) } \\
\cline { 2 - 3 } & Cycle I & Cycle II \\
\cline { 2 - 3 } & 61.97 & 77.0 \\
\hline
\end{tabular}

\section{The Students' Writing Skill in Vocabulary}

The improvement of the students' writing skill in vocabulary at the eighth grade students of SMP Unismuh Makassar as result of the students' assessment of cycle I and cycle II is described as follows:

Table 2: The Students' Improvement in Vocabulary

\begin{tabular}{|l|c|c|}
\hline \multirow{2}{*}{ Vocabulary } & \multicolumn{2}{|c|}{ Mean scores (\%) } \\
\cline { 2 - 3 } & Cycle I & Cycle II \\
\cline { 2 - 3 } & 58.15 & 73.5 \\
\hline
\end{tabular}

\section{The Improvement of Students' Writing Skill}

The improvement of students' writing skill by using FAIES method is deal with grammar and vocabulary. It can be seen clearly in the following table:

Table 3: The Students' Improvement in Writing Ability

\begin{tabular}{|c|c|c|}
\hline \multirow{2}{*}{ Variables } & \multicolumn{2}{|c|}{ Score (\%) } \\
\cline { 2 - 3 } & Cycle I & Cycle II \\
\hline Grammar & 62.15 & 77.0 \\
\hline Vocabulary & 58.15 & 73.5 \\
\hline$\sum \mathbf{x}$ & 120.12 & 150.5 \\
\hline$\overline{\boldsymbol{X}}$ & $60.1 \%$ & $75.25 \%$ \\
\hline
\end{tabular}

Table 4: The Students' Classification of Vocabulary and Grammar.

\begin{tabular}{|c|c|c|c|c|}
\hline No. & Classification & Score & Frequency & Percentage \\
\hline 1. & Excellent & $86-100$ & 4 & $15.4 \%$ \\
2. & Good & $70-85$ & 11 & $42.3 \%$ \\
3. & Fair & $56-69$ & 10 & $38.5 \%$ \\
4. & Poor & $41-55$ & 1 & $3.8 \%$ \\
5. & Very Poor & $\leq 40$ & 0 & $0.0 \%$ \\
\hline
\end{tabular}

4. The Improvement of the students' activeness in the process of teaching and learning

The result of the observation of the students' activeness improves in the process of teaching and learning toward the use of FAIES method. The observer conducts a classroom action research to improve the students writing 
ability at the eighth grade of SMP Unismuh Makassar which is conducted through 2 cycles during 8 meetings that is taken by observer through observation sheet. The result of students' activeness after doing the observation is presented in the following table:

Table 5: The Observation Result of the Students' Activeness in Teaching and Learning Process.

\begin{tabular}{|c|c|c|c|c|c|}
\hline \multirow{2}{*}{ Cycle } & \multicolumn{4}{|c|}{ Meetings } & \multirow{2}{*}{$\begin{array}{c}\text { Average } \\
\text { Score }\end{array}$} \\
\cline { 2 - 5 } & $\mathbf{1}^{\text {st }}$ & $\mathbf{2}^{\text {nd }}$ & $\mathbf{3}^{\text {rd }}$ & $\mathbf{4}^{\text {th }}$ & $59.9 \%$ \\
\hline I & $54.3 \%$ & $58.7 \%$ & $62.5 \%$ & $64.0 \%$ & $5.0 \%$ \\
\hline II & $66.4 \%$ & $58.7 \%$ & $73.1 \%$ & $77.9 \%$ & $69.02 \%$ \\
\hline
\end{tabular}

\section{DISCUSSION}

The research findings indicates that the students' writing ability through FAIES method show the improvement of the students' writing ability, from the improvement can be showed in the process from the cycle I to cycle II. The researcher has changed the activity to be more interesting in cycle II so that the students can show the improvement more significant than in cycle I. In cycle I the researcher give less motivation, less clear explanation and the real object which is given to the students less interesting related to the implementation of FAIES method. But in cycle II, the students very enjoy the method because the researcher gives more motivation, gives explanation intensively and uses funny story pictures which make the students more attracted.

At the beginning, the students is hard to understand the explanation and lazy to write recount text by their own word. Their ability in writing was still far from the target that wants to be reached by the researcher. But after reflected this problem, the researcher tries to resolve this problem by gives them more motivation, extensive explanation and also gives the real object which more interesting than before. The researcher asks the students about their difficulty to write recount text and gives explanation as the way to solve their problem and when the researcher gets the students' error, the researcher gives explanation about their error and asks them to change it in the correct form. As the result, the students become more active and easy to write which automatically improved the students' ability in writing skill. 
There are some processes that researcher can explain as follow:

1. The first meeting in cycle I, before gives material to the students the researcher gives them motivation. It is important because the researcher considers that each student comes to the class with their own thought and their own purposes so it is very important to unite the objective of the students before begin the teaching and learning process. Then the researcher gives the students material about recount text. It discusses what is recount text, the different between other text is and how to create a piece of recount text. Because FAIES method suggests giving the real object which related to the material, so the researcher gives the students a piece of diary which also as one form of recount text. The researcher gives explanation by using target language but sometimes followed by the native language its aim to make the students have become accustomed listen target language and naturally their vocabulary can improve. If there is an unfamiliar word for the students, the researcher will explain the meaning and gives good model of pronunciation then asks them to repeat it. After gives clear explanation, the researcher divides the students in pair then asks them to write a diary as their task. The last, the meeting is ended by giving the conclusion about the material to make the students understand it as a whole.

2. The second meeting in cycle I, the researcher gives the material about Simple Past Tense in verbal form. Same as the first meeting, the researcher gives the students motivation and the real object in this case the researcher gives the pictures as the example of simple past tense in infinitive, negative and interrogative form. The researcher explains it also by using target language and gives good model pronunciation with the new words which can appear. Then manages the students in pair and asks them to make some sentences of simple past tense as their task. And the last the meeting is ended by giving the conclusion about the material to make the students understand it as a whole.

3. The third meeting in cycle $\mathrm{I}$, the researcher gives the students material about Simple Past Tense in nominal form. The process of this meeting is same with the first and the second meeting, but the researcher find that the students are still difficult to make a recount text. 
4. The fourth meeting in cycle I, in this meeting the process is still same, the researcher gives material about Past Continuous Tense and pictures as real object which related to the material. By looking the picture each duo is asked to do the task about past continuous tense.

The result of FAIES method after applying action shows that the students' score is improving. This score is taken from students writing test in cycle I and calculating by using mean score and data analysis. After that the researcher uses the score of test to find out the students improvement percentage. The students' writing ability in cycle I is improve but the mean score was still low. It was about 60.1 , so the researcher decides to continue in cycle II.

5. The first meeting in cycle II, in this meeting the researcher still uses FAIES method. But in this cycle the researcher do not divide the students in pair but individually. Its aim to make each students be autonomous do their task and create a piece of writing. The researcher gives each student a funny story pictures without a title and they are asked to analyze that pictures. Then the researcher gives short explanation about that picture by using target language to stimulate their idea and asks them to give the title of the picture sequences then make recount text by retell the story in the pictures.

6. The second meeting in cycle II. The researcher has prepared untitled story pictures for the students. As usually the researcher opens the class by giving the students motivation before serve the material. Same at the previous meeting, the researcher divides the story pictures for each student and asks them to analyze the story picture. After they analyze it, the researcher asks them about the information that they have got from the story pictures. Next, researcher gives short explanation about it to connect the students' idea with the story picture. When the students have got the explanation, the researcher asks them to give the title of the pictures and make a recount text it. While the students are doing their task, the researcher controls each student' worksheet. If the error is found the researcher directly gives some correction and explains it. At this meeting the researcher observes that students can create a sentence 
with correct grammar but their vocabulary was still low despite they have progress in cycle I.

7. The third meeting in cycle II. The researcher gives the students story pictures which the title about COMING LATE. The process of this meeting is still same. In this meeting the students looked enjoy and easier make recount text. They can create it better than before.

8. The fourth meeting in cycle II. This is become the last meeting in cycle II and the process of teaching and learning is same as the meeting before. The researcher gives story pictures which title is about STOMACHACHE. In this meeting, the students are enthusiast, very active and enjoy in learning process. They can produce a good recount text and show well enough.

The result of cycle II in using FAIES method shows the students' improvement. The score is taken from students' writing test in cycle II and calculating by using the mean score in data analysis. And then the researcher uses the mean score in cycle I and cycle II to find out the students' improvement percentage. The students' improvement in using FAIES method have improved significantly form cycle I to cycle II, the mean score improve from 60.1 to 75.25.

As the result based on the findings above shown after calculating the students' score in cycle I and cycle II. It proves that the use of FAIES method can improve the students writing skill. The discussion dealing with the interpretation of findings derived from the result of finding about the observation result of students writing skill in terms of the result of students' activeness in teaching and learning process where grammar dealing with simple past tense and past continuous tense while vocabulary dealing with verb and noun.

\section{The improvement of students' writing grammar}

The improvement of students' writing grammar, the researcher finds that the mean score in D-test the students just get 42.5 and in cycle I is 62.15 . Then in cycle II is 77.0. Meanwhile there is a significant improvement after using FAIES method. In the pre-test and in the first cycle, the sense of students' grammar is vague for the readers. The researcher finds the students error in writing simple past and past continuous tense and they are still confusing to arranger the words into good sentence. The difficulty of the 
students in writing is analyzed by researcher. So, the researcher decides to do the cycle II by doing revision in the lesson plan which prepares in revision planning of cycle II. Where, the researcher explains about the step to write the correct sentence. The researcher also gives more examples about it. Besides, the researcher gives the better guidance for the students in writing good recount text. From explanation above, the researcher analyzes that the students' skill in writing recount text in term of grammar is improve, where the students mean score in cycle I and cycle II was higher than D-test.

\section{The improvement of students' writing vocabulary}

The improvement of the students' skill to write a good recount text by using FAIES method has effect that is effective. Where, the researcher finds in the data source of vocabulary that the students just get 53.8, it means that it is far from the target, but after application of FAIES method in cycle I the students score is 58.15 and 73.5 in the cycle II.

During the teaching and learning process in cycle $\mathrm{I}$, the researcher finds that vocabulary of the students also not use appropriate in the recount text. The students are difficult to write or express their ideas because they are lack of vocabulary. Therefore, the students are difficult in writing. The researcher decides to do cycle II by doing revision in the lesson plan which prepare in revision planning of cycle II. The result of revision planning to resolve the students' difficulty in writing is writing activity, the researcher gives explanation about the vocabulary that has to use in writing recount text and guides them to put the words in a sentence by using correct grammar. It is done consistently in each meeting so the students to be accustomed to use appropriate vocabulary in their writing.

\section{Observation Result}

Based on the data analysis as result of observation sheet of students' participation in learning process in previous findings shows that the participation of students from the first meeting till fourth meetings in cycle I are $54.3 \%, 58.7 \%, 62.5 \%$, and $64.0 \%$ with mean score $59.9 \%$. Percentage of the first till fourth meeting of the cycle II was $66.4 \%, 58.7 \%, 73.1 \%$ and 
$77.9 \%$ with the mean score $69.02 \%$. The improvement of the students' activeness in teaching and learning process from cycle I to cycle II is $9.12 \%$.

This FAIES method is new for the students, but in meeting by meeting they understand that the way of this method not only give them chance to work in pair but also motivate the students to make and present a good recount text. If they get difficulty of expressing their ideas, FAIES method can reduce this problem trough gives them real object. They can help each other. So, it is interested. FAIES method has positive social interaction behavior and attitude effects in teaching and learning process, because they work together as a partner, students needs to engage such interactive abilities as a leadership, trust building, conflict management, constructive criticism, encouragement, compromise, negotiation and clarifying. After they are good as team work FAIES also let them do their task individually which makes them become autonomous. Teacher needs descried expected social interaction behaviors and attitudes of the students and to assign particular students specific rules to ensure that they consciously work on these behaviors in their team work and guides them to be autonomous as individual person.

Finally, they know form of a good work in learning writing. It gives a good respond although their activeness not achieves $100 \%$ but they are good participants during learning and teaching process.

\section{BIBLIOGRAPHY}

Atkinson, Dwigt. 2003. L2 Writing in the Post-Process Era. Minato-ku. Tokyo.

Badger, Richard and White, Goodith. 2000. A process genre approach for teaching writing. Oxford University Press. Oxford.

Basri D, M. 2010. Fundamentals of Research Methodology. Makassar.

Byrne, D. 1990. Teaching Writing Skills. London and New York: Longma Handbooks for Language Teacher.

Cook, Guy. 1990. Discourse. Oxford University Press. Oxford.

Crystal, D. 2000. English As Global Language. Cambridge: Cambridge University Press. 
Deane, Paul and Fowless, mary. Using a Genre-Based Framework to teach organizational Structure in Academic Writing. Oxford University Press. Oxford.

Flowerdew, John. 1993. An educational, or process, approach to the teaching of professional genres. Oxford University Press. Oxford.

Fterniati, Anna and Spinthourakis Athena, Julia. 2006. Implementing a Text Oriented Approach to Effect Students' Textual Competence. Common Ground. http://www.learning-journal.com

Harmer, J. 1991. The Practice of English Language Teaching. London and New York: Longman Publishing, New York.

Hasan, Kamrul and Akhand, Moniruzzaman. 2010. Approaches to Writing in EFL / ESL Context Balancing Product and Process in Writing Class at Tertiary Level. http://www.Journal-NELTA.com. Vol. 15. No. 1-2.

Hossein H, 2012. A comparative study of product, process, post-process approach in Iranian EFL students' writing skill. Islamic Azad University. Iran.

Huddleston, Rodney. 1988. English Grammar. Cambridge University Press. Cambridge.

Hyland, Ken. 2002. Genre : Language, Context, and Literacy. Cambridge University Press. Cambridge.

Millar, Diane. 2011. Promoting Genre Awareness in the EFL Classroom. English Teaching Forum. Senegal.

Oshima, Alice and Hogue, Ann.1997.Introduction to Academic Writing. Longman.

Yan, Guo. 2005. A process genre model for teaching writing. English Teaching Forum (ETF). China.

Zaree, Abbas. 2008. The Effect of Teaching Genre Moves on EFL Learnes' Performance in Letter Writing. Kashan University. Kashan. 